\title{
The Narrative of Criminal Behaviour in Indonesian Literature by Female Author: Psychosocial Criminology Perspective
}

\author{
Anas Ahmadi
}

Universitas Negeri Surabaya, Indonesia

\begin{abstract}
Criminology studies, currently, are the most discussed subject from interdisciplinary perspectives. Hence, in this research, Indonesian literature written by the female author is studied using a psychosocial criminology perspective. One of the female authors in Indonesia who brings up criminology in her literary work is Dewi Lestari. She is an Indonesian novelist. The research problems are 1) How criminology depicted in Indonesian literature written by the female author is, and 2) Types of criminology depicted in Indonesian literature written by a female author. The method used in this research is qualitative interpretative. The collecting data technique in the literature study. The result shows that criminology in Indonesian literature is depicted explicitly. Whereas, types of criminology in Indonesian literature written by the female author are corruption, sex crimes, and transnational crimes related to endangered animal trade.
\end{abstract}

Keywords: Narrative, female author, psychosocial criminology.

\section{INTRODUCTION}

Criminal cases are classical issues. Even, it appears before the Socrates period, included the case faced by Socrates (Plato, Xenophon, \& Denyer, 2019) which is related to the death penalty. Nowadays, criminal cases which become criminology studies increase along with globalisation. It leads criminology studies to develop from mono-disciplinary studies into interdisciplinary, multidisciplinary, trans-disciplinary and integrative. The development of criminology studies is expected to be able to solve criminal cases which become more complex. Furthermore, criminology studies require various points of view and integration among scientific interdisciplinary (Bently, Davis\& Ginsburg, 2010; Mednick \& Lippens \& Murray, 2019; Reckless \& Shoham, 1979; Jeffery, 1990; Walsh \& Ellis, 2007). Through multidisciplinary criminology studies, the result will be holistic and up to date.

Criminology phenomena can be found in various scientific studies and also in literary works. Literature is contextual creative work (Ahmadi, 2019; 2020; Ahmadi, et al., 2019) which is one of them represents criminal behaviour (Colvin, 2015), either individual or group. Criminology study in the literature has become a global study (Schmid, 2018) because literature represents crimes in almost every country.

Representation of crimes with the various types in literature is a truth that literature cannot be separated from reality. The reality of crimes in literature is not entirely the same as reality in real life because the author as a literary creator combines reality and

*Address correspondence to this author at the Universitas Negeri Surabaya, Indonesia; E-mail: anasahmadi@unesa.ac.id

E-ISSN: 1929-4409/21 imagination. It leads the literature to become aesthetics. If literature depicts crime wholly, it will give the same points of views as news reported by mass media. Researchers who have studied literature studies related to criminology, namely murder theme (Peach, 2006; LaCroix, McAdams, \& Nussbaum, 2017; Time, 1999), bandit (Dabove, 2007), punishment and revenge (Sagarin, 1981), crimes toward women (Ward, 2014), murder technique (Past, 2017), crime-fighting figures, criminals, transnational crimes, white-collar crimes, and corruption.

Related to the relevance of literature studies using criminology perspective with the previous studies, there is not any researcher who studies literature using psychosocial criminology perspective. Even though, research on literature using psychosocial criminology perspective is a new breakthrough in criminology studies. Furthermore, if it is seen from the literature side, there is not any researcher who studies Indonesian literature using psychosocial criminology perspective. Through the psychosocial criminology perspective, a researcher can find the causes factors of criminal behaviours and their following motives. Based on the explanation, this research aims to narrate Indonesian literature written by the female author through criminology psychosocial perspective. Specifically, the problems of the research are 1) How criminology is depicted in Indonesian literature written by the female author is, and 2) Types of criminology depicted in Indonesian literature written by a female author.

Criminology studies essentially refer to criminal cases (Walklate, 2013). This research uses two approaches. Firstly, the psychosocial criminology approach is used. Psychosocial criminology essentially 
is an interdisciplinary study that relates between psychosocial and criminology disciplines (Gadd \& Jefferson, 2007; Kishi et al., 2018) to understand the psychology and sociology context of criminal behaviour happened in society. In fact, if it is looked deeper, psychosocial criminology study cannot be separated from psychology criminology study because it studies the motives of criminal behaviour, someone behaviour in doing the crimes, and the effects of criminal behaviour (Wortley, 2011; Cropley \& Cropley, 2013). Psychosocial criminology is an intersection of three scientific disciplines used to essentially understand the factors that caused criminal behaviours.

Secondly, the narrative criminology approach is used. This approach is used by the researcher because this research uses narrative text related to criminology study. In this case, literature is a narrative that contains criminology, either explicitly or implicitly. According to Colvin (2015), narrative criminology refers to criminology study which uses literature as data sources. Literary data sources which are in the form of a novel, short story, poetry, and drama are studied using literary criticism perspective and are linked to criminology perspective. Presser (2016:138) states that narrative criminology is connected with a narrative form which is emerged in a discourse. The narrative form has explicit and implicit meanings. Therefore, the emergence of a narrative is needed decipherment of meaning in order to find meaning contained in the narrative.

Narrative criminology in criticism study can be used as an approach or a method to analyse discursive text (Presser, 2013, 2012, 2009; Garot, 2018; Laws, 2020). In discourse context, the text that exists in society is not neutral and not objective because it has multiple interpretations. The multiple interpretations meaning needs deep understanding so that it does not lead to misleading interpretations. Moreover, a narrative cannot be separated from a ruler because he/she has the authority to control the narrative that exists in society. A ruler controls narrative because she/he has the authority to control media in society. If the media does not follow the orders, the media will be closed because it is considered to disobey the rules.

Criminal behaviour in criminology study is related to the environment (Beirne, 2007; Lynch, 2020), spiritual (Ronel \& Ben Yair, 2018), queer (Ball, 2014), gender (Chesney-Lind \& Chagnon, 2016), medicines (Moeller, 2017), psychology, and culture. Generally, criminology in society appears in the form of white-collar crimes, corporate crimes, corruption, domestic violence, violence against children and women, sex crimes (Tierney, 2006:9), and transnational crimes. As time goes by, these crimes have developed so that the classification of crimes in criminology study is still limited.

In relation to literature, a litterateur fights for righteousness through crimes depicted in the literature. They, the authors, tell about righteousness through their written literary works. Most of the authors who depict crimes in their literary works are male authors. Hence, in this research, the researcher tries to figure out how criminal behaviour is depicted in literary works written by a female author.

\section{METHOD}

This research uses the qualitative method which is linked to Creswell point of view (2017) that qualitative leads to the interpreting ability of the researcher in interpreting the text. The interpretation is based on the assumptions (Flick, 2018) constructed by the researcher according to the evidence. Data sources used in this research is Indonesian literature written by a female author named Dewi Lestari. The novels of Dewi Lestari are chosen because she is an Indonesian litterateur that is included in the litterateur of the 2000's generation. She also gets honour from Sea Write. The data collection technique is a literature study.

The data analysis technique is conducted by the researcher through some steps. Firstly, the researcher identifies the literary text fragmentary which has relevance with criminology. Secondly, the researcher identifies the literary text holistically which has relevance with criminology. Thirdly, after identifying holistically, the researcher classifies literary data which has relevance with criminology. Fourth, the classified data is selected into the main classification data. The main classification data is the data used in this research. Fifth is data description. At this step, the researcher describes the data based on the results of interpretation and literary criticism. Sixth is verification which is the final step. In this step, the researcher verifies the described data to be checked substantially to avoid errors in theoretical and methodological construction.

\section{RESULT AND DISCUSSION}

Literature as imaginative work cannot be separated from reality context. Hence, the literature describes 
reality in different forms. When criminal behaviour is found in reality, it is also depicted in literature. It is proven from the Supernova 1 novel, written by Dewi Lestari who is a female author, shows the representation of corruption behaviour in several contexts discussed below.

First is the representation of corruption behaviour in an education context. As an academic platform, education is not an area that is fully clear from corrupt behaviour. The corruption eradication in education is still in the process until now. However, corruption exists everywhere, includes education and it is hard to eradicate. It is showed in the data below.

\section{"...Atau lagi ada proyek pendidikan yang bisa dicatut?" (Lestari, 2001)}

In the novel, it is explained that education as an academic platform is not a holy platform like ordinary people thought. Education, in this novel, can be played and controlled by some people for individual/ groups benefits. The benefit is related to earn prosperity for individuals or for their group. It is proof of corrupt behaviour in the academic platform. The projects related to education are directed to certain projects and the amount of the projects is marked up. Money earns from marking up is used for the benefit of individuals or groups to get another education project.

The corruptor in the education context is hard to be arrested because they hide in the name of education. Therefore, in order to track corruption in education, the legal officer should be careful and accurate. Thus, corruptor in the education sector, if they are found guilty, they will be punished according to the current laws and regulations. Law is as a commander, so there is no different whosoever found guilty will be punished as fair as their criminal levels. However, sometimes, idealism and pragmatism go in contrast. In-laws, sometimes it is found injustice. Someone who does a big corruption punishes with minimum punishment, while someone who steals chicken punishes with maximum punishment. It proves that the law process and the people in those circles who do wrong, not the justice.

Corruption is a big theme in criminology studies. As known, corruption exists in several segments in life, such as politics, economics, society, culture and religion. In addition, corruption also exists in education. The emergence of corruption in education is caused by several factors, namely (1) the poor control of society, laws officers, and civitas academica in relation to corruption in the education sector; (2) mentality of people in the education sector that does not hold the ethics strictly so they fall into corruption hole, either individual or group; and (3) there is a chance to do the corruption by the people in the education sector because they are supported by other parties outside the education sectors, usually related to procurement or construction projects.

Secondly, in the novel entitled Supernova 1, the author strongly shows how sex crimes happen in modern society. Mostly, sex crimes tend to be done by a male towards female. In conclusion, a male is the villain of sex crimes, and a female is a victim. However, in the Supernova 1 novel, the author does not show the ordinary things usually happen in society. The author shows that sex crimes can be done by females towards a male. It can happen but it does not show up in mass media. The image of sexual behaviour is depicted in the following data.

God have mercy on your soul! Aduh, tololnya anak ini! Kamu mau tahu pengalaman pertama saya? Umur saya 16 tahun dan saya diperkosa tante-tante yang umurnya 45 tahun berdada bengkak berdagu silikon, okay! It was horrible! Look, saya tidak pernah menyukai Star. Tapi, kalau saya jadi kamu, saya akan mempersembahkan keperawananku di atas baki emas permata (Lestari, 2002:86).

The data shows that the male character confessed that he had become the victim of sex crimes. He was young at that time, 16 years old. He was raped by sugar mama. It shows explicitly that a female is able to do sex crimes against a male. Therefore, the female character in the novel entitled Supernova is not the rape victim, but the male character is the one who becomes the rape victim.

In the Supernova 3 novel: Petir, Dewi Lestari as the author, depicts criminology which is related to sex crimes. She showed clearly that the female character in the novel faced sexual harassment by her uncle when she was young. The children who face sexual harassment will get mental stress and then it becomes traumatic. If it is not handled correctly, the continuous trauma can affect the children so the children can be in a state of mental illness. Sex crimes and their effects are depicted clearly by Dewi Lestari in her novel. It showed in the following data. 
Ni Asih sebenarnya nenek malang yang terkena Split Personality Disorder. Masa kecilnya yang pahit karena sering disiksa ibu tiri dan korban pelecehan seksual paman tiri akhirnya membuat $\mathrm{Ni}$ Asih menciptakan sewujud Aki Jembros sebagai teman dalam kesendirian. Seiring bertambahnya usia, Ni Asih pun semakin lihai mengendalikan tombol on-off antara dirinya dan manusia imajinernya. Lalu bagaimana dengan semua kesaktian itu? Itu semua hoki (Lestari, 2004:58-59).

The character of Ni Asih in Supernova 3 novel got mental illness because she got sexual harassment in her past. Although she was older now, had become a grandmother, she could not get rid of past traumatic and she got a mental illness. The villain of sexual harassment, in this case, was her uncle, who did not feel guilty although he was the one who commits the sex crimes. The worst, he was not arrested because of his action.

Sexual harassment cases committed by a male toward female mostly are free to be done (Sa'dāwī, 1998). It causes by several factors. First, sexual harassment victim does have the bravery to report the cases because the victim is usually under pressure and intimidated by the villain. If the victim reports the case to the police officer, he/ she will get hurts or abuse by the villain. It causes a great fear of the victim. Second, the victim does have the bravery to report the cases to the police officer because feels ashamed. Most of the sexual harassment victims feel ashamed to report it to the police officer because sexual crime is a disgrace for a woman who becomes the victim. If the society hears about the news of sexual harassment, usually the victims of sex crime tend to be excommunicated by the society because she is recognized dirty. Third, the villain is a part of the victim's family, it makes the victim does not want and feel ashamed to report because it is a disgrace to the family's reputation. Hence, there are many sex crimes that are not reported.

In Supernova 4 novel, Dewi Lestari depicts criminal behaviour which is related to environmental destruction. Environment destruction that happens in modern society is related to several things. First, environmental destruction is related to natural resources extraction of living things. The recent modern human is in a race to extract natural resources for individual or group benefits. The corporate extracts natural resources while ignoring the effects on the environment. Therefore, there are damaged forests because of deforestation, a landslide in the mountain because of excavation so the land lost the mineral. Second, environmental destruction is related to living things. Examples are whaling, rare bird catching, and animals hunting for medicines or industries. It leads to animal extinction because they are caught and killed. Here is the proof that shows orang-utan hunting and killing in Supernoval 4 novel.

...orangutan yang terbunuh itu adalah
orangutan asli alam bebas yang belum
pernah dibesarkan di kamp (Lestari
2016:5).

According to the data, it shows that orang-utan is dead because of being hunted by animal hunters. The endangered animals are hunted and sold to people that like to collect rare animals. The endangered animal's price is high. In addition, hunters who like to hunt endangered animals get self-satisfaction by hunting the animals. As the animals are hard to get, the selfsatisfaction is higher.

There are many crimes done by humans toward animals, such as the hunt for the leather of the animals like snakes or crocodiles. The two animals are hunted for leather. It can be made for a bag or jacket. The leather of animals that are produced for bags and jackets has a high price because it is original leather, not the synthetics one. It affects snakes and crocodiles to become extinct because they are always hunted for leather. Besides the leather, the fin of the shark is hunted for shark-fin soup or other foods. Shark-fin contains many minerals needed by a human. Therefore, a shark is one of the animals which is hunted.

Endangered animals trade does not only become a national issue but also cross country and becomes transnational. It is called transnational crime which is related to extinct animals trading. It is a big crime because it is across the country and involves some countries. Therefore, catching up with the transnational crimes network is hard work to do. Even, if the countries are indicated involve in endangered animals trade, the countries tend to have low weak laws.

Anak-anak orangutan lainnya yang tidak beruntung diselundupkan di kapal tanpa makan dan minum hingga Singapura dan Hongkong, untuk kemudian diperdagangkan di jaringan internasional 
untuk menjual satwa langka secara gelap

(Lestari, 2016).

The data shows that endangered animals trade becomes a business across the countries so it becomes a transnational crime. Transnational crimes in relation to endangered animals trade is a part of environmental destruction (Taylor \& Fitzgerald, 2018). It is in line with the perspective of Boratto \& Gibbs (2019), Lynch (2020), Goyes \& Sollund (2018), Donovan \& Coupe (2013) that animals trade is environmental destruction because the trade leads to animals extinction.

Endangered animals trade tend to take aim on young animals because it is easy to be smuggled. Besides, young animals are easy to be taken care of and tamed by the adopter. To catch babies or young animals in the forest is easier than the bigger one. Big animals tend to be hard to get because they are agile so the hunters get difficulties in catching the big animals. Therefore, adopter of endangered animals tends to adopt baby or young animals. As the request for rare animals higher, the endangered animal's trade increase.

Dewi Lestari as a female author speaks up through her novel that it is important to save the environment for now and for a better future. Therefore, in her novel, she shows that woman can take apart to save the environment by being volunteers that take part in rescuing rare animals in the jungle. Environment rescue from environmental crimes is important because it can lead to natural imbalance if it is not rescued. If this issue is ignored, as time goes by, the environment will be damaged, includes humans as the ecosystem of the environment.

\section{CONCLUSION}

Literature as the voice of the author cannot be separated from the psychosocial of society. Therefore, it represents various things; one of them is criminal behaviour. The novel written by Dewi Lestari, depicts that the criminal behaviours in literature can be in the form of (1) corruption behaviour in the education sector. Corruption in education has a tight relationship with projects in education, either related to procurement or construction; (2) sex crime behaviour done by a male toward female and vice versa. Nevertheless, Dewi Lestari as the author emphasizes sex crime behaviour done by a male toward a female. In this case, a woman becomes the victim of sex crimes. Even, in the novel written by Dewi Lestari, it is shown that females who got sexual harassment got mental illness in the end. It proves that sex crimes are dangerous and can damage the victims. Unfortunately, most of the villain is laws-free; and (3) behaviour of transnational crimes, namely endangered animals hunting which is traded to dark market or even across the countries. The three problems show criminal behaviour which exists in Indonesian literature.

Dewi Lestari as a female author is able to universally show that literature is the voice of truth. In this case, the truth showed by Dewi Lestari is related to problems of criminal behaviour that exist in Indonesia and in the world. Crime in several countries is a harmful act for other countries universally. Hence, crimes should be banned into their root, at least by sounding it from literature.

\section{REFERENCES}

Ahmadi, A. (2020). Promoting personality psychology through literary learning: An appreciative-reflective study. International Journal of Innovation, Creativity and Change, 11 (7):529-540, https://www.ijicc.net/index.php/volume-12-2020/174-vol-12iss-8

Ahmadi, A. (2019) Teachers as psychologist:Experience in beginner level of creative writing classes using behavior modification. International Journal of Learning, Teaching and Educational Research, 18 (12): 101-115. https://doi.org/10.26803/ijlter.18.12.7

Ahmadi, A., Ghazali, A.S., Dermawan, T. \& Maryaeni. (2019). Ecopsychology and psychology of literature: Concretization of human biophilia that loves the environment in two indonesian novels. The International Journal of Literary Humanities 17 (1): 47-59. https://doi.org/10.18848/2327-7912/CGP/v17i01/47-59

Ball, M (2014) Queer criminology, critique, and the 'art of not being governed'. Critical Criminology 22(1): 21-34. https://doi.org/10.1007/s10612-013-9223-2

Ball, M (2016). Criminology and queer theory: Dangerous bedfellows? London; New York: Palgrave Macmillan. https://doi.org/10.1057/978-1-137-45328-0

Boratto, R., \& Gibbs, C. (2019). Advancing interdisciplinary research on illegal wildlife trade using a conservation criminology framework. European Journal of Criminology. https://doi.org/10.1177/1477370819887512

Bently, L., Davis, J., \& Ginsburg, J. C. (2010). Copyright and piracy: An interdisciplinary critique. Leiden: Cambridge University Press. https://doi.org/10.1017/CBO9780511761577

Beirne, P. (2007). Animal rights, animal abuse and green criminology. In Beirne, P., South, N. (Eds.), Issues in green criminology (pp. 55-86). Oxford, England: Willan.

Colvin, S. (2015). Why should criminology care about literary fiction? Literature, life narratives and telling untellable stories. Punishment \& Society, 17(2), 211-229. https://doi.org/10.1177/1462474515577152

Cropley, D. \& Cropley, A. J. (2013). Creativity and crime: A psychological analysis. Cambridge: Cambridge University Press. https://doi.org/10.1017/CBO9781139176118 
Chesney-Lind, M., \& Chagnon, N. (2016). Criminology, Gender, and Race: A Case Study of Privilege in the Academy. Feminist Criminology, 11(4), 311-333. https://doi.org/10.1177/1557085116633749

Creswell, J. (2017). Types of qualitative research. Thousand Oaks, USA : SAGE Publications Inc

Dabove, J. P. (2007). Nightmares of the lettered city: Banditry and literature in Latin America, 1816-1929. Pittsburgh, PA: University of Pittsburgh Press. https://doi.org/10.2307/j.ctt7zw8hj

Donovan, J., \& Coupe, R. T. (2013). Animal rights extremism: Victimization, investigation and detection of a campaign of criminal intimidation. European Journal of Criminology, 10(1), 113-132. https://doi.org/10.1177/1477370812460609

Flick, U. (2018). Managing quality in qualitative research. Los Angeles: Sage. https://doi.org/10.4135/9781529716641

Garot, R. (2018). Narrative criminology. Malden: Willey. https://doi.org/10.1111/socf.12410

Gadd, D., \& Jefferson, T. (2014). Psychosocial criminology. Place of publication not identified: SAGE Publications Ltd.

Goyes, D. R., \& Sollund, R. (2018). Animal abuse, biotechnology and species justice. Theoretical Criminology, 22(3), 363-383. https://doi.org/10.1177/1362480618787179

Jeffery, C. R. (1990). Criminology: An interdisciplinary approach. Englewood Cliffs, N.J: Prentice Hall.

Kishi, K., Suzuki, J., Monma, T., Asanuma, T., \& Takeda, F. (2018). Psychosocial and criminological factors related to recidivism among Japanese criminals at offender rehabilitation facilities. Cogent Social Sciences, 4(1), 1-13. https://doi.org/10.1080/23311886.2018.1489458

Laws, B. (2020). Reimaging 'the Self' in Criminology: Transcendence, Unconscious States and the Limits of Narrative Criminology. Theoretical Criminology. https://doi.org/10.1177/1362480620919102

LaCroix, A. L., McAdams, R. H., \& Nussbaum, M. C. Eds. (2017). Fatal fictions: Crime and investigation in law and literature. https://doi.org/10.1093/acprof:oso/9780190610784.001.0001

Lestari, D. (2001). Supernova 1: Puteri, ksatria, dan bintang jatuh. Jakarta: Truedee Book.

Lestari, D. (2004). Supernova 3: Petir. Yogyakarta: Bentang.

Lestari, D. (2016). Supernova 5: Intelegensi Embun Pagi. Yogyakarta: Bentang.

Lippens, R., \& Murray, E. (2019). Representing the Experience of War and Atrocity: Interdisciplinary Explorations in Visual Criminology. https://doi.org/10.1007/978-3-030-13925-4

Lynch, M. J. (2020). Green Criminology and Environmental Crime: Criminology That Matters in the Age of Global Ecological Collapse. Journal of White Collar and Corporate Crime, 1(1), 50-61. https://doi.org/10.1177/2631309X19876930

Mednick, S. A., \& Shoham, S. G. (1979). New paths in criminology: Interdisciplinary and intercultural explorations. Lexington, MA: Lexington Books.
Moeller, K. (2017). Drug Market Criminology. International Criminal Justice Review, 28(3), 191-205. https://doi.org/10.1177/1057567717746215

Past, E. M. (2017). Methods of Murder: Beccarian Introspection and Lombrosian Vivisection in Italian Crime Fiction. Toronto : University of Toronto Press

Peach, L. (2006). Criminal Deceptions: Criminal Deceptions. Basingstoke: Palgrave Macmillan.

Plato, Xenophon, \& Denyer, N. (2019). Plato: The Apology of Socrates and Xenophon: The Apology of Socrates. Cambridge: Cambridge University Press.

Presser, L. (2012). Getting on top through mass murder: Narrative, metaphor, and violence. Crime, Media, Culture, 8(1), 3-21. https://doi.org/10.1177/1741659011430443

Presser, L. (2016). Criminology and the narrative turn. Crime, Media, Culture, 12(2), 137-151. https://doi.org/10.1177/1741659015626203

Presser, L. (2013). Narrative criminology. New York: Oxford University Press. https://doi.org/10.1093/obo/9780195396607-0171

Presser, L. (2009). The narratives of offenders. Theoretical Criminology, 13(2), 177-200. https://doi.org/10.1177/1362480609102878

Sa'dāwī, El (1998). The innocence of the devil. Berkeley: University of California Press.

Sagarin, E. (1981). Raskolnikov and others: Literary images of crime, punishment, redemption, and atonement. New York: St. Martin's Press.

Schmid, D. Eds. (2016). Globalization and the state in contemporary crime fiction: A world of crime. London : Palgrave Macmillan

Taylor, N., \& Fitzgerald, A. (2018). Understanding animal (ab)use: Green criminological contributions, missed opportunities and a way forward. Theoretical Criminology, 22(3), 402-425. https://doi.org/10.1177/1362480618787173

Time, V. M. (1999). Shakespeare's criminals: Criminology, fiction, and drama. Westport, Conn: Greenwood Press.

Reckless, W. C., \& Newman, C. L. Eds. (1965). Interdisciplinary problems in criminology: Papers of the American Society of Criminology, 1964. Columbus, Ohio: Publication Service, College of Commerce and Administration, Ohio State University.

Ronel, N., \& Ben Yair, Y. (2018). Spiritual Criminology: The Case of Jewish Criminology. International Journal of Offender Therapy and Comparative Criminology, 62(7), 2081-2102. https://doi.org/10.1177/0306624X17693865

Ward, I. (2014). Sex, crime and literature in Victorian England. Oxford : Hart Pub. https://doi.org/10.1080/09589236.2014.959304

Wortley, R. (2011). Psychological criminology: An integrative approach. New York: Routledge. https://doi.org/10.4324/9780203806098

Walsh, A., \& Ellis, L. (2007). Criminology: An interdisciplinary approach. Thousand Oaks: SAGE Publications.

Walklate, S. (2003). Understanding Criminology. Milton Keynes: Open University Press.

Received on 28-05-2021

Accepted on 26-07-2021

Published on 04-08-2021

https://doi.org/10.6000/1929-4409.2021.10.148

(C) 2021 Anas Ahmadi; Licensee Lifescience Global.

This is an open access article licensed under the terms of the Creative Commons Attribution Non-Commercial License (http://creativecommons.org/licenses/by-nc/3.0/) which permits unrestricted, non-commercial use, distribution and reproduction in any medium, provided the work is properly cited. 